Review

\title{
New-Generation Antibiotics for Treatment of Gram-Positive Infections: A Review with Focus on Endocarditis and Osteomyelitis
}

\author{
Annemieke Bloem *, Hannelore I. Bax, Erlangga Yusuf $(\mathbb{D}$ and Nelianne J. Verkaik \\ Department of Medical Microbiology and Infectious Diseases, Erasmus University Medical Center Rotterdam, \\ 3015 GD Rotterdam, The Netherlands; h.bax@erasmusmc.nl (H.I.B.); e.yusuf@erasmusmc.nl (E.Y.); \\ n.j.verkaik@erasmusmc.nl (N.J.V.) \\ * Correspondence: annemiekebloem@gmail.com; Tel.: +31-10-703-3510
}

Citation: Bloem, A.; Bax, H.I.; Yusuf, E.; Verkaik, N.J. New-Generation Antibiotics for Treatment of Gram-Positive Infections: A Review with Focus on Endocarditis and Osteomyelitis. J. Clin. Med. 2021, 10, 1743. https://doi.org/10.3390/ jcm10081743

Academic Editor: Olivier Mimoz

Received: 15 February 2021

Accepted: 3 April 2021

Published: 17 April 2021

Publisher's Note: MDPI stays neutral with regard to jurisdictional claims in published maps and institutional affiliations.

Copyright: (c) 2021 by the authors. Licensee MDPI, Basel, Switzerland. This article is an open access article distributed under the terms and conditions of the Creative Commons Attribution (CC BY) license (https:/ / creativecommons.org/licenses/by/ $4.0 /)$.
Abstract: Infective endocarditis, osteomyelitis, and osteosynthesis-associated infections are mostly caused by Gram-positive bacteria. They are often difficult to treat and are associated with a poor prognosis. In the past 20 years, nine antibiotic drugs with predominant activity against Grampositive bacteria have been introduced and approved by the Food and Drug Administration or the European Medicines Agency: ceftaroline, daptomycin, telavancin, dalbavancin, oritavancin, linezolid, tedizolid, delafloxacin, and omadacycline. This narrative review aims to provide an overview on these antibiotics with a special focus on their use in infective endocarditis, osteomyelitis, and osteosynthesis-associated infections. Although some of these approved antibiotics are promising, they should not be used as first- or second-line therapy, awaiting more clinical data.

Keywords: endocarditis; osteomyelitis; prosthetic joint infection; Gram-positive; new-generation antibiotics

\section{Introduction}

Infective endocarditis (IE), osteomyelitis, and osteosynthesis-associated infections (OAI) are infectious diseases that are difficult to treat and associated with a poor prognosis $[1,2]$. The majority of these infections are caused by Gram-positive micro-organisms, including methicillin-resistant Staphylococcus aureus (MRSA) and vancomycin-resistant Enterococcus faecium (VRE). To treat these infections, usually a combination of surgery and antibiotic treatment is needed. However, antibiotic treatment may be challenging due to high bacterial loads, difficulty of antibiotics to achieve adequate drug concentrations at the site of infection, and biofilm formation [3,4].

In the past 20 years, several antibiotics with predominant activity against Grampositive bacteria have been developed and approved by the Food and Drug Administration (FDA) or the European Medicines Agency (EMA). Although most of these antibiotics are not approved for these indications, they might also be used to treat IE, osteomyelitis, and osteosynthesis-associated infections. Previous reviews have been published on the use of just a few of these novel antibiotics in complicated infections $[5,6]$. Other reviews focused on the use of these novel antibiotics for approved indications [7-11]. Instead, the aim of this review is to provide an overview of nine of these new antibiotics with a special focus on their use in the treatment of IE, osteomyelitis, and osteosynthesis-associated infections.

\section{Materials and Methods}

We first identified antibiotics with predominant activity against Gram-positive cocci that were approved by the FDA and/or EMA after 2000. Next, we performed a literature search in MEDLINE to identify (preferably clinical or, if not available, animal or in vitro) studies published or accepted for publication since 2000 on the use of these antibiotics for the indications as mentioned above. As such, the search term of each antibiotic 
agent was combined with "endocarditis", "osteomyelitis", "prosthetic joint infection", and "bacteremia". Studies were selected on the basis of title and abstract, only articles published in English were reviewed. Published studies on pediatric patients ( $<18$ years) were not included.

\section{Results}

\subsection{Ceftaroline}

Ceftaroline is the only FDA and EMA approved beta-lactam antibiotic with activity against methicillin-resistant Staphylococcus aureus (MRSA), which is due to its high affinity for PBP2a [12]. Next to its in vitro activity against $S$. aureus, ceftaroline is active in vitro against coagulase-negative staphylococci (CoNS) and streptococci but shows no activity against E. faecium. The activity of ceftaroline against Enterococcus faecalis varies, with minimum inhibitory concentrations (MICs) between 0.12 and $32 \mathrm{mg} / \mathrm{L} \mathrm{[13,14].}$

Ceftaroline is approved by the FDA and EMA for acute bacterial skin and skin structure infection (ABSSSI) and community-acquired pneumonia (CAP) with an approved dose of $600 \mathrm{mg}$ b.i.d. (bis in die/twice daily) IV (intravenous) (Table 1). Several studies showed that increasing the dose to $600 \mathrm{mg}$ t.i.d. (ter in die/thrice daily), which can be used to treat infections due to $S$. aureus with ceftaroline MICs of $\geq 2 \mathrm{mg} / \mathrm{L}[15,16]$, is safe and well tolerated $[17,18]$. The clearance is predominantly renal and dose adjustment is required when creatinine clearance is below $50 \mathrm{~mL} / \mathrm{min}$ (Table 1).

Ceftaroline in Infective Endocarditis and Osteomyelitis

A phase IV registry (CAPTURE) included 55 patients with proven IE (26 right sided, 25 left sided, 4 bilateral) of which $80 \%$ was caused by MRSA [19]. Patients were treated for a median of 11 days (range $2-45$ days). During this time, $41.8 \%$ of patients received ceftaroline monotherapy and $58.2 \%$ received ceftaroline with concurrent antibiotics $(34.5 \%$ daptomycin, $16.4 \%$ vancomycin, and $12.7 \%$ rifampin). In all, $70.9 \%$ of the cases showed clinical cure or improvement $(80.8 \%$ in right-sided IE, $68.0 \%$ in left-sided IE, but only $25 \%$ in bilateral IE). The monotherapy group improved in $82.6 \%$ of cases, whereas $62.5 \%$ of patients receiving combination therapy showed improvement. However, this could be due to the selection of patients. Of the 44 cases caused by MRSA, $77.3 \%$ achieved clinical success. No difference in success rate was observed between patients receiving $600 \mathrm{mg}$ b.i.d. or t.i.d.

The same registry evaluated 150 patients with osteomyelitis (62\% caused by MRSA, $21.3 \%$ had osteosynthesis-associated infections) of whom $14.7 \%$ underwent surgery [20]. The majority $(76 \%)$ of these patients received other antibiotics prior to ceftaroline (of which $54 \%$ received vancomycin). Moreover, $66.7 \%$ of patients (100/150) received ceftaroline monotherapy, and the rest of the patients received concurrent therapy (of which $36 \%$ were on metronidazole). Median treatment duration was 6 days (range 2-45 days). In this study, clinical success (i.e., cure or improvement based on individual physician assessment) was achieved in $92.7 \%$ of the patients. No data were presented on the subgroup with osteosynthesis-associated infections.

For both indications, it is important to note the short duration of ceftaroline treatment in these studies. This could be partly explained by the fact that it was often used as secondline or rescue treatment. This makes it very complicated to draw conclusions on the efficacy of ceftaroline for these indications. The same applies for a retrospective analysis of 29 patients with MRSA bloodstream infections (BSIs), of whom 15 cases had IE (four right sided, 11 left sided), three cases had cardiac device infections, and nine cases had soft tissue or bone infection [21]. These patients received ceftaroline for a minimum of three days, and all patients received prior antibiotic treatment. No sub-analysis was performed for IE or osteomyelitis. Overall, in nine patients, treatment was considered successful, four patients were considered as treatment failures, and seven patients were lost to follow-up. 


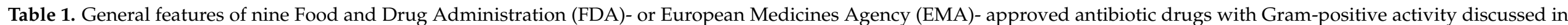
this paper.

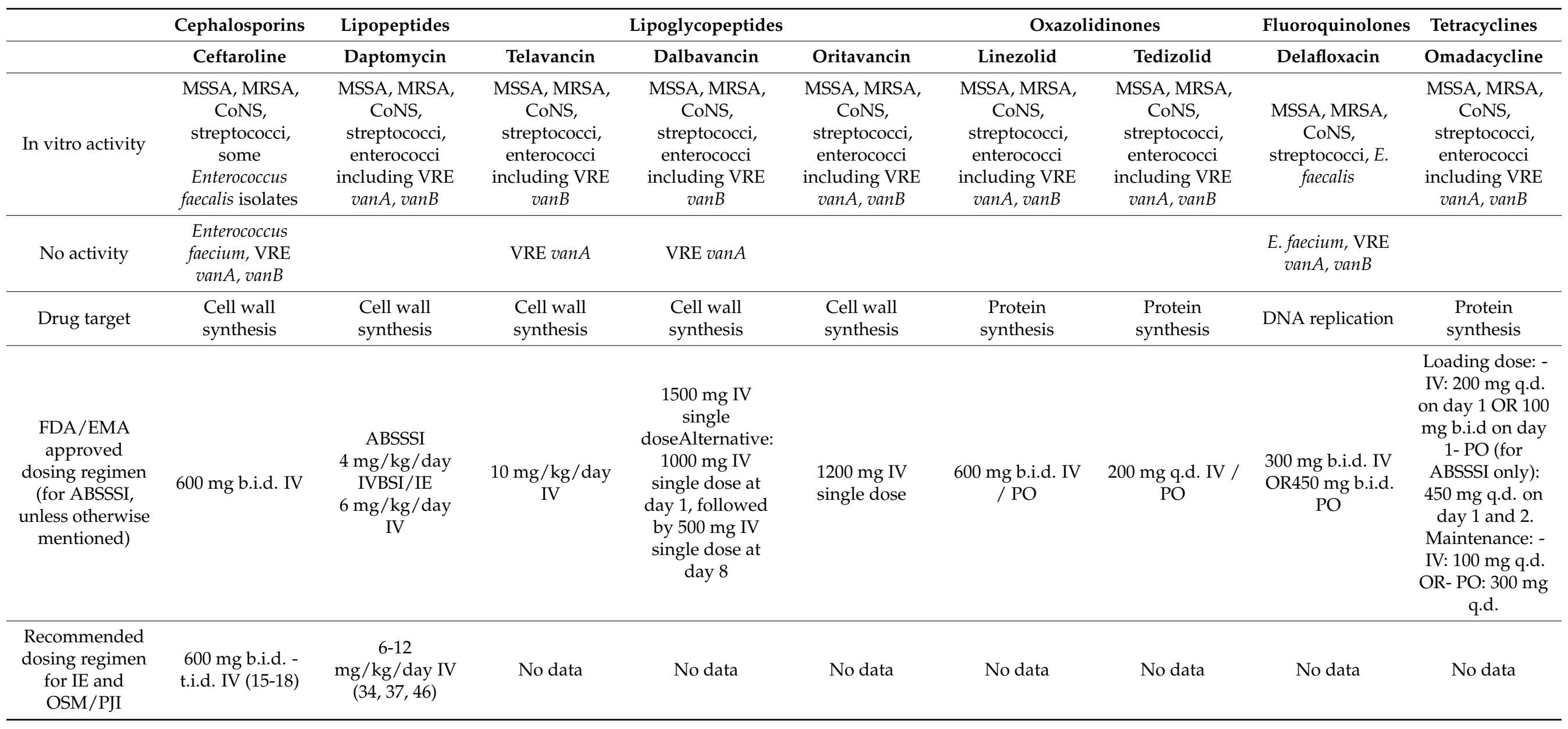


Table 1. Cont.

\begin{tabular}{|c|c|c|c|c|c|c|c|c|c|}
\hline & \multirow{2}{*}{$\begin{array}{c}\text { Cephalosporins } \\
\text { Ceftaroline }\end{array}$} & \multirow{2}{*}{$\begin{array}{c}\text { Lipopeptides } \\
\text { Daptomycin }\end{array}$} & \multicolumn{3}{|c|}{ Lipoglycopeptides } & \multicolumn{2}{|c|}{ Oxazolidinones } & \multirow{2}{*}{$\begin{array}{c}\text { Fluoroquinolones } \\
\text { Delafloxacin }\end{array}$} & \multirow{2}{*}{$\begin{array}{c}\text { Tetracyclines } \\
\text { Omadacycline }\end{array}$} \\
\hline & & & Telavancin & Dalbavancin & Oritavancin & Linezolid & Tedizolid & & \\
\hline $\begin{array}{c}\text { Dose } \\
\text { adjustments }\end{array}$ & $\begin{array}{l}\text { Creatinine } \\
\text { clearance: } \\
\text { 30-50 } \\
\text { mL/min: } 400 \\
\text { mg b.i.d. IV; } \\
\text { 15-30 mL/min } \\
\text { 300 mg b.i.d.; } \\
\text { - ESRD/HD: } \\
200 \text { mg b.i.d. }\end{array}$ & $\begin{array}{c}\text { Creatinine } \\
\text { clearance }<30 \\
\text { mL/min, HD, } \\
\text { CAPD: } \\
6 \mathrm{mg} / \mathrm{kg} \mathrm{IV} \\
\text { every } 48 \mathrm{~h}\end{array}$ & $\begin{array}{c}\text { Creatinine } \\
\text { clearance:- } \\
30-50 \mathrm{~mL} / \mathrm{min} \\
7.5 \mathrm{mg} / \mathrm{kg} / \text { day } \\
-<30 \mathrm{~mL} / \mathrm{min} \\
10 \mathrm{mg} / \mathrm{kg} \\
\text { every } 48 \mathrm{~h}\end{array}$ & $\begin{array}{c}\text { Creatinine } \\
\text { clearance < } 30 \\
\mathrm{~mL} / \mathrm{min}: \\
750 \mathrm{mg} \text { IV } \\
\text { single dose at } \\
\text { day } 1, \text { followed } \\
\text { by } 375 \mathrm{mg} \text { IV at } \\
\text { day } 8\end{array}$ & $\begin{array}{c}\text { Not } \\
\text { recommended in } \\
\text { mild or moderate } \\
\text { impairment, } \\
\text { pharmacokinet- } \\
\text { ics in patients } \\
\text { with severe renal } \\
\text { impairment has } \\
\text { not been } \\
\text { evaluated }\end{array}$ & None & None & $\begin{array}{c}\text { Creatinine } \\
\text { clearance 15-29 } \\
\text { mL/min: } \\
200 \text { mg b.i.d. IV. } \\
\text { No dose } \\
\text { adjustment PO. }\end{array}$ & None \\
\hline $\begin{array}{l}\text { Points of } \\
\text { interest }\end{array}$ & $\begin{array}{c}\text { Only } \\
\text { approved } \\
\text { cephalosporin } \\
\text { active against } \\
\text { MRSA }\end{array}$ & $\begin{array}{l}\text { Not indicated } \\
\text { for pneumoni- } \\
\text { aMonitor CPK } \\
\text { and renal } \\
\text { function once } \\
\text { weekly }\end{array}$ & $\begin{array}{c}\text { Renal } \\
\text { dysfunction } \\
\text { observed more } \\
\text { often compared } \\
\text { with } \\
\text { vancomycin }\end{array}$ & $\begin{array}{l}\text { Single dose } \\
\text { therapy }\end{array}$ & $\begin{array}{l}\text { Single dose } \\
\text { therapy }\end{array}$ & $\begin{array}{l}\text { Oral formulation } \\
\text { available with } 100 \% \\
\text { oral bioavailabilityRisk } \\
\text { of myelosuppression } \\
\text { after prolonged use }>14 \\
\text { days, monitoring } \\
\text { recommended }\end{array}$ & $\begin{array}{c}\text { Oral } \\
\text { formulation } \\
\text { available with } \\
91 \% \text { oral } \\
\text { bioavailability }\end{array}$ & $\begin{array}{c}\text { Oral } \\
\text { formulation } \\
\text { available with } \\
58.8 \% \text { oral } \\
\text { bioavailability }\end{array}$ & $\begin{array}{c}\text { Oral } \\
\text { formulation } \\
\text { availableAde- } \\
\text { quate oral } \\
\text { bioavailability } \\
\text { only in fasted } \\
\text { state }(\geq 4 \mathrm{~h} \\
\text { before and } 2 \mathrm{~h} \\
\text { after dose) }\end{array}$ \\
\hline $\begin{array}{l}\text { FDA approval } \\
\text { (year, brand } \\
\text { name, and } \\
\text { indications) }\end{array}$ & $\begin{array}{l}\text { 2010, Teflaro }{ }^{\circledR}, \\
\text { ABSSSI, CAP }\end{array}$ & $\begin{array}{c}\text { 2003, } \\
\text { Cubicin }{ }^{\circledR}, \\
\text { ABSSSI, } \\
\text { right-sided } \\
\text { infective } \\
\text { endocarditis } \\
\text { SA, } \\
\text { bacteremia SA }\end{array}$ & $\begin{array}{c}\text { 2009, Vibativ }{ }^{\circledR} \\
\text { ABSSSI, HAP, } \\
\text { VAP }\end{array}$ & $\begin{array}{c}\text { 2014, Xydalba }{ }^{\circledR} \\
\text { ABSSSI }\end{array}$ & $\begin{array}{c}\text { 2014, Orbactiv }{ }^{\circledR} \\
\text { ABSSSI }\end{array}$ & $\begin{array}{l}\text { 2000, Zyvox }{ }^{\circledR},- \text { ABSSSI } \\
\text { (including diabetic foot } \\
\text { infection, without } \\
\text { osteomyelitis) caused } \\
\text { by MSSA, MRSA, } \\
\text { Streptococcus pyogenes, } \\
\text { Streptococcus agalactiae= } \\
\text { HAP caused by MSSA, } \\
\text { MRSA, Streptococcus } \\
\text { pneumoniae- CAP } \\
\text { caused by S. pneumoniae } \\
\text { (incl. BSI), MSSA- VRE } \\
\text { infections incl. BSI }\end{array}$ & $\begin{array}{c}\text { 2014, } \text { Sivextro }^{\circledR} \\
\text { ABSSSI }\end{array}$ & $\begin{array}{l}2017 \text { and } 2019 \\
\text { Baxdela }{ }^{\circledR} \\
\text { ABSSSI (2017), } \\
\text { CAP (2019) }\end{array}$ & $\begin{array}{c}\text { 2018, Nuzyra }{ }^{\circledR}, \\
\text { ABSSSI, CAP }\end{array}$ \\
\hline
\end{tabular}


Table 1. Cont.

\begin{tabular}{|c|c|c|c|c|c|c|c|c|c|}
\hline & \multirow{2}{*}{$\begin{array}{c}\text { Cephalosporins } \\
\text { Ceftaroline }\end{array}$} & \multirow{2}{*}{$\begin{array}{c}\text { Lipopeptides } \\
\text { Daptomycin }\end{array}$} & \multicolumn{3}{|c|}{ Lipoglycopeptides } & \multicolumn{2}{|c|}{ Oxazolidinones } & \multirow{2}{*}{$\begin{array}{c}\text { Fluoroquinolones } \\
\text { Delafloxacin }\end{array}$} & \multirow{2}{*}{$\begin{array}{c}\text { Tetracyclines } \\
\text { Omadacycline }\end{array}$} \\
\hline & & & Telavancin & Dalbavancin & Oritavancin & Linezolid & Tedizolid & & \\
\hline $\begin{array}{l}\text { EMA approval } \\
\text { (year, brand } \\
\text { name, and } \\
\text { indications) }\end{array}$ & $\begin{array}{c}2012, \\
\text { Zinforo }^{\circledR} \\
\text { ABSSSI, CÁP }\end{array}$ & $\begin{array}{c}\text { 2006, } \\
\text { Cubicin }^{\circledR}, \\
\text { ABSSI, } \\
\text { right-sided } \\
\text { infective } \\
\text { endocarditis } \\
\text { SA, } \\
\text { bacteremia SA }\end{array}$ & $\begin{array}{l}\text { Not EMA } \\
\text { approved }\end{array}$ & $\begin{array}{c}\text { 2015, Xydalba }{ }^{\circledR}, \\
\text { ABSSSI }\end{array}$ & $\begin{array}{l}\text { 2015, Orbactiv }{ }^{\circledR} \\
\text { ABSSSI }\end{array}$ & $\begin{array}{c}\text { 2001, Zyvox }{ }^{\circledR}, \text { ABSSSI, } \\
\text { HAP, CAP }\end{array}$ & $\begin{array}{l}\text { 2015, } \text { Sivextro }^{\circledR} \\
\text { ABSSSI }\end{array}$ & $\begin{array}{l}2019, \\
\text { Quofenix }{ }^{\circledR}, \\
\text { ABSSSI }\end{array}$ & $\begin{array}{l}\text { Not EMA } \\
\text { approved }\end{array}$ \\
\hline
\end{tabular}

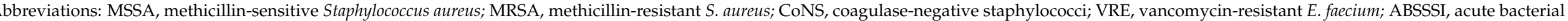

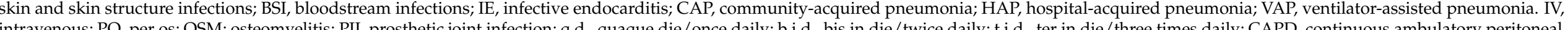
dialysis; ESRD, end-stage renal disease; HD, hemodialysis; CPK, creatinine phosphokinase; FDA, Food and Drug Administration; EMA, European Medicines Agency; SA, S. aureus. 
Several studies have been published on the use of ceftaroline in bacteremia, whether or not in combination with other antimicrobial agents. Some of these studies also included IE and osteomyelitis cases.

In a retrospective study on 141 patients with BSI, the clinical success rate of ceftaroline therapy was 79\% [22]. Part of these patients (approximately 30\%) were treated with ceftaroline $600 \mathrm{mg}$ t.i.d. Seventy-five patients with bone and joint infections were included, with an observed success rate in this group of $95 \%$. No further information about this subgroup is provided.

A retrospective case control study on 32 patients with MRSA bacteremia showed higher microbiological and clinical success of ceftaroline compared to vancomycin, although not statistically significant [23]. A retrospective comparative study on MRSA BSI (among which there were seven IE and eight osteomyelitis cases) showed similar clinical success for ceftaroline monotherapy $(n=30)$ compared to daptomycin or vancomycin in terms of relapse, readmission, and 30 day mortality [24].

As for combination therapy with ceftaroline, evidence from in vitro studies indicates synergism between ceftaroline and daptomycin [25-28], which was retained in daptomycinresistant isolates [28]. However, clinical studies are inconclusive. A multicenter observational study that included 211 patients with MRSA BSI showed a similar success rate for ceftaroline monotherapy compared to combination therapy (71.7\% with daptomycin) [29]. A retrospective review described 11 patients with complicated MRSA BSI, treated with either ceftaroline and daptomycin or ceftaroline and vancomycin [30]. The microbiological cure was $100 \%$ for both treatment options, and there were no relapses at 30 or 60 days. A retrospective matched cohort study on MRSA BSI included 58 patients who were treated with daptomycin and ceftaroline and compared these with 113 patients who received standard of care (96\% vancomycin) [31]. A lower mortality, a faster clearance of bacteremia and a lower rate of relapse and recurrence were observed with combination treatment, albeit not statistically significant. One open-label randomized controlled trial (RCT) in patients with MRSA BSI compared the duration of bacteremia with ceftaroline and daptomycin combination therapy to vancomycin or daptomycin monotherapy [32]. This study was terminated prematurely due to an unexpected observed in-hospital mortality difference of $0 \%(0 / 17)$ versus $26 \%(6 / 23)$ in favor of combination therapy with no difference in duration of bacteremia between the (small) groups. Larger prospective trials are needed in order to draw more solid conclusions on the role of ceftaroline-daptomycin combination therapy in this setting.

\subsection{Daptomycin}

Daptomycin is a cyclic lipopeptide antibiotic with bactericidal activity against staphylococci, streptococci, and enterococci including VRE and MRSA [33]. It has different mechanisms of action including disruption of cell membrane function and inhibition of protein, DNA, and RNA synthesis.

Daptomycin is approved by the FDA and EMA for ABSSSI at a dose of $4 \mathrm{mg} / \mathrm{kg} / \mathrm{day}$ IV and for S. aureus BSI and right-sided IE due to $S$. aureus at a dose of $6 \mathrm{mg} / \mathrm{kg} / \mathrm{day}$ IV. Increasing the dose up to $10 \mathrm{mg} / \mathrm{kg}$ q.d. (quaque die/once daily) seemed to be tolerated well [34]. An important adverse event of daptomycin is elevation of creatine phosphokinase (CPK), which can be accompanied by rhabdomyolysis [35]. Therefore, at least once-weekly $\mathrm{CPK}$ monitoring is required. Clearance of daptomycin is predominantly renal, and dosage adjustment is required when creatinine clearance is $<30 \mathrm{~mL} / \mathrm{min}[33,36]$.

\section{Daptomycin in Infective Endocarditis and Osteomyelitis}

A study in predominately streptococcal native valve IE (NVIE) that compared 84 patients with a daptomycin-containing regimen (DCR, either monotherapy or in combination with other antibiotics) to 140 patients with non-daptomycin-containing regimens (nonDCR), showed that the 30 day mortality in patients with a DCR was higher than in the patients with a non-DCR $(27.4 \%$ vs. $19.3 \%)$, albeit not significant [37]. In the same study, 
61 patients with predominately staphylococcal prosthetic valve IE treated with daptomycincontaining regimens had significant lower 30 day mortality than those without daptomycin $(6.5 \%$ vs. $38 \%, p<0.001)$. This study also reported that the group of NVIE patients receiving a standard dose of daptomycin (4-6 mg/ kg/day) showed a two times higher mortality risk (odds ratio $2.2,95 \%$ CI 1.91-4.56, $p=0.02$ ) compared to the group receiving a higher dose of daptomycin (>8 mg/kg/day).

The efficacy of daptomycin seems to be highly dose dependent. One systematic review and meta-analysis on daptomycin use in VRE bacteremia showed a significantly higher 30 day mortality for daptomycin compared to linezolid [38]. However, in this study, no doses higher than $6 \mathrm{mg} / \mathrm{kg} /$ day were reported. Another systematic review and meta-analysis on this topic also showed a significantly higher 30 day mortality for daptomycin standard dose (6 mg/kg/day) compared to linezolid [39]. A subset analysis on high-dose daptomycin showed no difference in mortality compared to linezolid. Similarly, several publications on VRE and MRSA BSI and IE showed a survival benefit for daptomycin dosages of $\geq 7,8,9$, or $10 \mathrm{mg} / \mathrm{kg} /$ day [40] compared to standard dose [41-43] or vancomycin [44].

The European Cubicin ${ }^{\circledR}$ Outcomes Registry and Experience (EU-CORE) study investigated daptomycin treatment in 638 patients with osteomyelitis (224 cases of non-prosthetic osteomyelitis, 208 cases of osteomyelitis related to permanent or temporary orthopedic devices, and 206 cases with orthopedic device infections) [45,46]. A majority of the infections were caused by S. aureus (49.1\% of the cases, of which half was MRSA), followed by CoNS $(35.1 \%)$, streptococci, and enterococci. In this study, cure or improvement was shown in $81.8 \%$ of the patients $(80.3 \%$ for osteomyelitis and $85 \%$ in prosthetic- or osteosynthesismaterial-related infection). The majority (61.9\%) of the patients also underwent surgical intervention and $71.3 \%$ received prior antibiotic treatment.

A systematic review that summarized the outcome of 233 osteomyelitis patients (of which 184 were associated with osteosynthesis material and 115 with septic arthritis or osteomyelitis) treated with daptomycin confirmed the high clinical cure rate [46]. The clinical cure rate was $70 \%$ in patients with orthopedic device infections and $78 \%$ in osteomyelitis and septic arthritis cases. This study also showed that clinical cure rate (defined as total resolution of signs and symptoms or improvement to such an extent that no further antibiotic treatment was necessary) depends on the dose. Clinical cure rate was $85 \%$ in patients who received a dose of $10 \mathrm{mg} / \mathrm{kg} /$ day (interquartile range (IQR) 67-92), 85\% for 6-8 mg/kg/day (IQR 63-95), and 71\% for 4-6 mg/kg/day (IQR 58-80).

As for daptomycin combination therapy, several studies have been published. For daptomycin in combination with rifampin, in vitro models show diverse results from possible antagonism in an experimental endocarditis model [47] to increased efficacy [48] and bactericidal activity in biofilm-embedded bacteria in S. aureus biofilms [49]. Increased efficacy was also shown for combination therapy in an experimental MRSA foreign-body-infection model [50]. In response to the experimental endocarditis study [47] with possible antagonism, in vitro checkerboard assays were performed, which did not show antagonism [51].

In an experimental endocarditis model in rabbits, daptomycin and fosfomycin showed synergy and rapid bactericidal activity [52]. In an RCT on MRSA BSI and IE with 155 patients, treatment success rate was $12 \%$ higher for daptomycin in combination with fosfomycin compared to daptomycin monotherapy, albeit not statistically significant [53].

As discussed in the ceftaroline section, daptomycin and ceftaroline combination therapy might have a positive effect on clinical outcome [32].

\subsection{Telavancin}

Telavancin is a semisynthetic lipoglycopeptide antibiotic engineered to be an improved alternative to the available glycopeptides, vancomycin and teicoplanin. It shows in vitro activity against methicillin-sensitive $S$. aureus (MSSA), MRSA, CoNS, streptococci, and VRE vanB but not vanA [54]. 
Telavancin is FDA approved for ABSSSI, hospital acquired pneumonia (HAP), and ventilator-assisted pneumonia (VAP) in a dosing regimen of $10 \mathrm{mg} / \mathrm{kg} /$ day. It was initially EMA approved for use in nosocomial pneumonia and VAP caused by MRSA but was withdrawn in 2018 because of commercial reasons [55]. Clearance is predominantly renal, and dose adjustment is needed when creatinine clearance is $<50 \mathrm{~mL} / \mathrm{min}$ [56]. Telavancin is associated with increased creatinine levels more often than vancomycin [57]. Moreover, adverse drug reactions led to the discontinuation of therapy more often in the telavancintreated patients $(8 \%)$ than in the vancomycin-treated patients $(5 \%)$.

The FDA required a Risk Evaluation and Mitigation Strategy (REMS), as part of the drug safety program, because an increased mortality rate was observed in telavancintreated patients with $\mathrm{HAP} / \mathrm{VAP}$ with a pre-existing creatinine clearance of $\leq 50 \mathrm{~mL} / \mathrm{min}$, and also fetal toxicity was observed in animal models [58,59]. Since 2017, a REMS is no longer required [60].

\section{Telavancin in Infective Endocarditis and Osteomyelitis}

Published data on the use of telavancin in IE is limited and mostly concerns case reports [61-63]. One case series that included 14 cases treated with telavancin for refractory MRSA bacteremia after antibiotic treatment with vancomycin or daptomycin showed that 8 of 14 patients (57\%) survived inpatient admission and were eligible for follow-up [64]. Four of them underwent surgery. Patients who died all had mitral valve IE. Among the six patients who died, one underwent valve replacement and the other five cases were not considered surgical candidates. The median duration of bacteremia was 12 days (range 3-26 days). Patients received vancomycin and, in some cases, daptomycin. Median time to achieve sterilization (in 10 patients) was 1 day (1-3 days) following initiation of telavancin.

In a large observational study, 151 patients with bacteremia (13 with IE) were treated with telavancin (57.6\% MRSA) [65]. The overall median treatment duration was 9 days but was not specified for IE. Among the 11 IE patients for whom follow-up data were available, eight patients had a positive outcome (seven were cured and one improved; three patients failed) at end of telavancin therapy [65]. In this study, overall, 74.2\% had a positive outcome, defined as either cure or partial response (with possible further need for telavancin therapy).

Three observational studies have been published regarding telavancin for the treatment of osteomyelitis and osteosynthesis-associated infections. These studies included 14 [66], 60 [67], and 32 [68] patients with osteomyelitis, of which $64 \%, 37 \%$, and $15 \%$ had osteosynthesis material, respectively. In the first study, surgery was performed in $57 \%$ of patients $(8 / 14)$, but this was not specified in the latter two. Clinical success, defined as resolved or improved infection, was $78 \%, 73 \%$, and $92 \%$ with a median treatment duration of 58 days (9-66), 41 days (3-179), and 31.5 days (6-94), respectively. MRSA was the most frequently isolated pathogen $(100 \%, 67 \%$, and $57 \%$, respectively) [66-68].

For uncomplicated MRSA bacteremia, telavancin has been proven to be equally or more effective compared to vancomycin [69,70]. A large observational study described 1065 patients who were treated with telavancin for a median treatment duration of 10 days (range 5-26 days) [71]. Positive clinical outcome, either cure (defined as resolution of signs and symptoms and no need for additional therapy) or improvement to stepdown therapy, was reached in $77.7 \%$. Of these 1065 cases, $27.4 \%$ concerned bone and joint infections and $14.2 \% \mathrm{IE}$, a positive outcome was reported in $74.2 \%$ and $78.7 \%$ of the cases, respectively. No further information on these subgroups was reported.

\subsection{Dalbavancin}

Dalbavancin is a semisynthetic lipoglycopeptide antibiotic, with a half-life of approximately 8.5 days, enabling weekly dosing regimens or single-dose therapy in the treatment of ABSSSI. It shows in vitro activity against MSSA, MRSA, CoNS, and streptococci, E. faecalis and E. faecium, including VRE vanB but not vanA [72]. 
Dalbavancin is approved by the FDA and EMA for ABSSSI in a dosing regimen of $1500 \mathrm{mg}$ IV as a single dose or alternatively $1000 \mathrm{mg}$ IV on day 1, followed by $500 \mathrm{mg}$ IV on day 8 . Both regiments have similar rates of adverse events $[73,74]$. Dalbavancin is predominately excreted via the urine. Dosage adjustment is recommended when renal clearance is $<30 \mathrm{~mL} / \mathrm{min}$ [72].

\section{Dalbavancin in Infective Endocarditis and Osteomyelitis}

A retrospective multicenter study on off-label use of dalbavancin for IE $(n=25)$, osteomyelitis $(n=30)$, OAI $(n=32)$, ABSSSI, and catheter-related BSI showed promising results, with an $89 \%$ overall success rate (defined as no clinical, microbiological, or laboratory evidence of persistent or recurring infection at 90 days), with particular good results for IE (91.3\%) and OAI (92.7\%) [75]. Different dosing regimens were used, and the median number of administrations was three. No information was provided on whether or not surgery is performed.

A clinical cure rate (i.e., no BSI recurrence or IE relapse/reinfection, no mortality) of $85.3 \%$ was observed during a 12 month follow-up in an observational study assessing dalbavancin efficacy in 83 patients with BSI, of whom 34 had proven IE $(20.6 \%$ MSSA, $8.8 \%$ MRSA, $44.1 \%$ coagulase-negative staphylococci (CoNS), 20.6\% streptococci, and 8.8\% E. faecalis) [76]. All patients received prior antibiotics, and surgery was performed in 10 of 15 patients with prosthetic valve IE, 7 of 8 pacemaker lead IE, and 5 out of 11 native valve IE.

A high proportion of clinical cure $(92.6 \%)$ was also observed in an observational study of 27 patients with proven IE, of which there were 16 native valve, 6 prosthetic valve, and 5 cardiac device-related IE, caused by CoNS (76.7\%) and S. aureus (33.3\%) [77]. Patients were treated with dalbavancin with a median treatment duration of six weeks (range 1-30 weeks) and combined with surgery in 11 patients. In this study, failures were observed in two patients only (one due to non-infective postoperative complications and one due to incomplete surgical source control). However, the majority of the patients (24 of 27) received other antibiotics and already had microbiological clearance prior to dalbavancin; so, it was not clear whether the clinical success was attributable to dalbavancin. The three patients who received dalbavancin as primary therapy showed no relapse at six months follow-up.

One RCT has been published on dalbavancin treatment for osteomyelitis. In this RCT, which did not include patients with osteosynthesis-associated infections, patients were randomized to a two-dose regimen of dalbavancin $1500 \mathrm{mg}$ on day 1 and $8(\mathrm{n}=70)$, or standard-of-care $(n=10, n=3$ vancomycin monotherapy, $n=7$ vancomycin combined with either linezolid or levofloxacin) [78]. All patients underwent baseline debridement. In this study, MSSA and MRSA were causative pathogens in 54.3\% and 5.7\% of cases, respectively. The primary endpoint, defined as recovery without the need for additional antibiotic treatment at day 42 , was reached in $97 \%$ in the dalbavancin group and $88 \%$ in the comparator group. Clinical significance was not reported, probably due to the small comparator group.

In an observational study with prolonged use of dalbavancin (median five doses), 64 patients with osteomyelitis and septic arthritis (45 with osteosynthesis-associated infections) were included [79]. In the patients with osteosynthesis material, S. epidermidis was the most common causative pathogen, in the rest of the patients the most common causative pathogen was S. aureus (93.9\% MRSA). Clinical cure (i.e., absence of clinical signs of infection at the latest medical visit, without the need for additional surgery or antibiotic treatment) was reached in $68.8 \%$ of patients with osteosynthesis-associated infections (65.2\% with implant retention and $76.1 \%$ with implant removal) and $73.6 \%$ in the remaining patients.

For catheter-related BSI, in a phase 2 study with 75 patients, dalbavancin therapy showed a significantly higher success rate than vancomycin (87\% vs. 50\%) [80]. Further- 
more, dalbavancin seems to be a promising option for outpatient parenteral antibiotic therapy [81] or long-term suppression therapy [82].

As for dalbavancin combination therapy, an MRSA foreign-body-infection model with infected cages in guinea pigs was used to determine the efficacy of dalbavancin in combination with rifampin [83]. Dalbavancin in combination with rifampin cured $36 \%$ of the infected cages. A similar cure rate was observed with rifampin monotherapy. During rifampin monotherapy, rifampin resistance was observed in 38\% of the treatment failures. In combination therapy, rifampin resistance was reduced from $25 \%$ to $0 \%$ by increasing dalbavancin dosages from 40 up to $80 \mathrm{mg} / \mathrm{kg}$. No dalbavancin resistance was observed.

\subsection{Oritavancin}

Oritavancin is another semisynthetic lipoglycopeptide antibiotic with a long half-life, providing the opportunity of weekly dosing. The spectrum of activity is largely similar to that of dalbavancin but with additional activity against VRE vanA [84,85].

Oritavancin is approved by the FDA and EMA for ABSSSI as a single dose of $1200 \mathrm{mg}$ IV. Its clearance is predominantly renal, but dose adjustment is not recommended in mild-to-moderate renal impairment. No pharmacokinetic data are available for severe renal impairment $[84,86]$. In contrast to dalbavancin, oritavancin is a weak inhibitor of certain cytochrome P450 enzymes $[84,87,88]$. Oritavancin also interacts with several laboratory tests due to its ability to bind to the phospholipid reagent, preventing the activation of coagulation in commonly used laboratory coagulation tests, among which were activated Partial Thromboplastin Time (aPTT) and Prothrombin Time (PT) [89].

\section{Oritavancin in Infective Endocarditis and Osteomyelitis}

The long half-life of oritavancin provides clear practical advantages in the treatment of infections that need long-term antibiotic treatment such as IE and osteomyelitis. Weekly dosing can improve compliance. However, only a limited number of papers (case reports) have been published on the use of oritavancin, especially for IE.

In a case report, a patient with recurrent VRE bacteremia due to native aortic and mitral valve IE was successfully treated with 10 weeks of oritavancin treatment $(1200 \mathrm{mg}$, twice weekly) in combination with valve replacement surgery [90].

A recent, multicenter, retrospective descriptive study described 134 patients with acute osteomyelitis [91]. They received four or five doses of oritavancin $(1200 \mathrm{mg}$, followed by $800 \mathrm{mg}$ weekly). MRSA was the cause for $71.9 \%$, while $6.7 \%$ had concurrent MRSA BSI. Clinical success (defined as resolution of symptoms or improvement of symptoms and no further need for treatment) was achieved in $88.1 \%$. Debridement was performed in $90.3 \%$ of the cases. Another retrospective observational program described 438 patients who received at least one dose of oritavancin [92]. Among them, 32 cases were considered complicated infections, of which 18 cases concerned osteomyelitis, three concerned osteosynthesis-associated infections, and seven patients had BSI. Clinical success (defined as cure or improvement after 30 days) was achieved in $93.8 \%$ of the complicated infections. For the patients who received one single dose, clinical success was $87.7 \%$ and for multiple dosages it was $93.7 \%$. Prior antibiotics were administered in $71.4 \%$ of the cases.

\subsection{Linezolid}

Linezolid is a synthetic bacteriostatic agent of the oxazolidinone class of antibiotics and selectively inhibits bacterial protein synthesis. Linezolid is the only antibiotic drug mentioned in this review that is approved for the treatment of VRE infections, including bacteremia, and is available both in IV and PO formulation. Linezolid shows in vitro activity against MSSA, MRSA, CoNS, streptococci, and enterococci, including vanA and vanB VRE [93].

Linezolid is approved by the FDA and EMA for ABSSSI, HAP, and CAP. The FDA also approved linezolid for infections due to VRE, including VRE bacteremia. Its approved dosing regimen is $600 \mathrm{mg}$ b.i.d. IV/PO. Linezolid has an oral bioavailability of $100 \%$ 
with or without food [94,95]. Linezolid is predominantly excreted (partly unchanged) in urine. No dose adjustment is needed in renal failure $[93,96]$. When the treatment duration is shorter than two weeks, linezolid is generally well tolerated, but longer treatment duration is associated with an increased risk of myelosuppression, in particular reversible thrombocytopenia $[97,98]$. Therefore, patients with (prolonged) linezolid treatment should be monitored for myelosuppression, particularly in patients with renal impairment [99].

Linezolid in Infective Endocarditis and Osteomyelitis

In a systematic review of published case reports, cure (defined as clinical improvement, negative blood cultures, and no evidence of persistent vegetation on echocardiography) was investigated in 33 IE patients. Of the patients, $66.7 \%$ received linezolid monotherapy, $84.8 \%$ received prior antibiotic treatment, and $24 \%$ underwent surgical intervention [100]. MRSA and vancomycin-intermediate $S$. aureus were the most commonly isolated cocci ( $24.2 \%$ and $30.3 \%$ of cases, respectively). Cure was shown in $63.6 \%$ of the patients. Higher success rates were reported in two small observational studies. In a study of 14 patients, in which linezolid was used as follow-up therapy for 3 weeks and all patients underwent valve replacement surgery and prior vancomycin treatment, a 100\% success rate (i.e., clearance of symptoms and the absence of persistent bacteremia) was found [101]. Another study that included nine patients ( $<50 \%$ underwent surgery, $44.4 \%$ was caused by MSSA, and $22.2 \%$ by MRSA and all received prior antibiotics for a median length of 22 days) showed a clinical cure rate of $100 \%$, with no relapses during follow-up (mean follow-up duration of 8.5 months) [102].

A study that assessed linezolid efficacy in 55 patients with osteomyelitis (70.9\% without prosthetic material, $16.4 \%$ with prosthetic material removed, and $12.7 \%$ without prosthetic material removal), showed clinical cure, defined as the resolution of signs and symptoms, in $81.8 \%$ after a median of 189 days [103]. Subgroup analysis in patients with osteomyelitis caused by VRE showed a $93.9 \%$ cure rate at short-term follow-up (7 to 10 days after discontinuation of linezolid). One patient with VRE infection was available for longterm follow-up (one month after discontinuation of linezolid), and this patient was cured. Smaller studies also show high cure rates. As such, a 100\% cure rate (i.e., clinical recovery, normalization of inflammatory markers, and no need for reoperation or rehospitalization) was shown in a study in 22 patients with chronic osteosynthesis-associated infection (18 associated with fracture fixation and four with arthroplasties), with 14 patients available for follow-up after 6 months [104]. All patients underwent surgery (debridement and removal of all implants), and $45 \%$ of the infections were caused by MRSA. Use of antibiotics other than linezolid was not specified. Another study in 11 patients with osteomyelitis (45\% of the infections were caused by MRSA, all patients underwent surgery), of which two were implant-related, also showed $100 \%$ remission according to clinical, laboratory, and radiographic criteria [105].

Linezolid is approved by the FDA for the treatment of VRE BSI. Comparative studies of linezolid and daptomycin are discussed in the daptomycin section.

In the case of persistent MRSA bacteremia ( $\geq 7$ days), linezolid proved to be statistically more effective than vancomycin in terms of early microbiological response, success rate, and mortality rate [106]. However, statistical significance for better outcome was not confirmed by another study on the same topic [107].

As for linezolid combination therapy, an in vitro model for staphylococcal biofilm showed significantly increased biofilm activity of linezolid in combination with rifampin compared to that of linezolid monotherapy [108]. This combination did not lead to rifampin resistance. However, levofloxacin with or without rifampin was still more effective. A retrospective study compared linezolid in combination with rifampin to cotrimoxazole in combination with rifampin in 56 bone and joint infections [109]. No difference was observed in either efficacy or tolerance. 


\subsection{Tedizolid}

Like linezolid, tedizolid belongs to the oxazolidinone class of drugs and is available in an oral formulation with the same spectrum of activity, including activity against VRE [110,111].

Tedizolid is approved for ABSSSI by the FDA and EMA in a dosing regimen of $200 \mathrm{mg}$ q.d. PO or IV. Oral bioavailability is $91 \%$ and independent of food intake [112]. Clearance is predominantly hepatic, but dose adjustment is not required in both hepatic and renal impairment [113]. Treatment duration of 6 days for ABSSI was shown to be non-inferior to 10 days of linezolid therapy $[114,115]$. Like linezolid, tedizolid is associated with thrombocytopenia, albeit with lower frequency than linezolid [116], which might be partly explained by the shorter treatment duration of tedizolid ( 6 days) compared to that of linezolid (10 days). Similar to linezolid, the proportion of patients with thrombocytopenia has been shown to increase when the treatment duration is prolonged and in patients with chronic renal failure.

\section{Tedizolid in Infective Endocarditis and Osteomyelitis}

To the best of our knowledge, no clinical data on tedizolid efficacy in patients with IE and osteomyelitis have been published. An in vitro study in a biofilm model showed that tedizolid was not effective in eradicating mature S. aureus and S. epidermidis biofilms [117].

A rabbit model of MRSA aortic valve IE showed that tedizolid and vancomycin were less effective than daptomycin after 4 days of treatment [118]. However, in a rat endocarditis model, the efficacy of 2 days of tedizolid step-down therapy after 3 days of daptomycin administration was similar to that of daptomycin for 5 days, which might suggest a role for tedizolid step-down therapy [119]. Caution is needed in extrapolating these results to humans.

In a rat model of MRSA and methicillin resistant Staphylococcus epidermidis (MRSE) osteosynthesis-associated infections, tedizolid for 21 days, either alone or in combination with rifampin, reduced bacterial counts $[120,121]$. This was comparable to vancomycin with or without rifampin, and bacterial counts were significantly lower than in the nontreatment group.

As for combination therapy, in an in vitro model of endocardial vegetations, antagonism was observed when tedizolid was combined with daptomycin [122].

\subsection{Delafloxacin}

Delafloxacin belongs to the fluoroquinolone class of drugs and is active in vitro against MSSA, MRSA, CoNS, and streptococci. Interestingly, delafloxacin retains activity against fluoroquinolone-resistant $S$. aureus strains [123-126]. Specific features in the delafloxacin molecule lead to enhanced activity in acidic environment due to its anionic character, which eventually leads to improved activity $[127,128]$. According to EUCAST, there is insufficient evidence that enterococci are a good target for therapy with delafloxacin.

Delafloxacin was approved by the FDA and EMA for ABSSSI and additionally for CAP by the FDA. The approved dose is $300 \mathrm{mg}$ b.i.d. IV and $450 \mathrm{mg}$ b.i.d. PO. Oral bioavailability is approximately $58-70 \%$ [129,130]. The oral dose of $450 \mathrm{mg}$ leads to a similar total exposure to that of $300 \mathrm{mg}$ IV and is not affected by food intake $[129,131]$. Clearance is predominantly renal, and dose adjustment for the IV formulation is required when creatinine clearance is below $30 \mathrm{~mL} / \mathrm{min}$. No adjustment is needed either for the oral formulation or in hepatic impairment [132]. Like other fluoroquinolones, delafloxacin may be associated with increased risk of serious adverse events, such as tendon ruptures and tendinitis, and aneurysmatic and neurological complications, for which the FDA issued a fluoroquinolone box warning [133]. Since specific data on delafloxacin are still limited, the occurrence of side effects should be monitored closely [134]. 
Delafloxacin in Infective Endocarditis and Osteomyelitis

No clinical data have been published on the use of delafloxacin for IE and osteomyelitis. In general, other fluoroquinolones such as ciprofloxacin, levofloxacin, and moxifloxacin are known to be efficacious in treating osteomyelitis, including osteosynthesis-associated infections, due to their ability to eradicate biofilm formation on osteosynthesis material surface [123]. An in vitro study using biofilm models with 96-wells plates confirms the ability of delafloxacin to reduce $S$. aureus biofilm viability and depth $[135,136]$. In this study, its biofilm penetration was also deeper in comparison to that of daptomycin and vancomycin, perhaps due to its smaller molecular mass and increased activity in an acidic environment $[127,136]$.

\subsection{Omadacycline}

Omadacycline is a member of a new subclass of tetracyclines. It shows in vitro activity against MSSA, MRSA CoNS, streptococci, and enterococci including VRE [137,138].

Omadacycline is FDA approved for the treatment of ABSSSI and CAP and is available both in IV and oral formulation. The approved dosing regimen for ABSSSI requires a loading dose of $200 \mathrm{mg}$ q.d. IV or $100 \mathrm{mg}$ b.i.d. IV on day 1, or $450 \mathrm{mg}$ q.d. PO on day 1 and 2. The maintenance dose is $100 \mathrm{mg}$ q.d. IV or $300 \mathrm{mg}$ q.d. PO. Despite limited oral bioavailability (34.5\%), similar exposure can be achieved with $300 \mathrm{mg}$ PO as with $100 \mathrm{mg}$ IV [139]. Adequate oral bioavailability can only be achieved in the fasted state $\geq 4 \mathrm{~h}$ before and $2 \mathrm{~h}$ after intake. EMA approval of omadacycline was withdrawn in 2019 by the authorization holder because, according to EMA, the benefits of the drug did not outweigh the risks. Although omadacycline treatment in patients with CAP was non-inferior compared to moxifloxacin treatment, an unexplained imbalance in mortality rate was noticed at the expense of omadacycline [140]. Although this could not be solely attributed to omadacycline, it did lead to a negative benefit-to-risk ratio according to the EMA [141]. Approval for ABSSSI only was not considered advantageous from a commercial point of view. Omadacycline is primarily excreted unchanged in feces and secondarily excreted in urine [139], but no dose adjustment is needed in impaired renal or hepatic function [142]. Omadacycline has comparable adverse events to other tetracyclines such as tooth discoloration, enamel hypoplasia, and inhibition of bone growth. However, no cases of photosensitivity were observed in the phase III registration studies that included 1073 patients [143].

Omadacycline in Infective Endocarditis and Osteomyelitis

No clinical data or case reports are available on omadacycline use in IE or OSM/ prosthetic joint infection (PJI). Omadacycline distributes extensively throughout the body, and excellent bone tissue penetration has been shown in animal models [138,139].

\section{Discussion and Concluding Remarks}

We reviewed nine antibiotics with predominant Gram-positive activity and focused on the treatment of IE and osteomyelitis (including osteosynthesis-associated infections). For some antibiotics such as ceftaroline, daptomycin, and linezolid, a number of clinical studies are available. For most of the described antibiotics, however, clinical data are limited. It is difficult to assess the efficacy because the evidence is mostly observational, and patients often received prior or concurrent antibiotics. Dosing regimens are quite diverse, and in some studies patients, were included after receiving only one dose of the study drug. Furthermore, for IE and OAI, surgical intervention is frequently necessary, and whether or not this is performed might have significantly impacted treatment results.

Another limitation of this narrative review is the risk of bias, particularly selection bias, with incomplete retrieval of publications as a result. However, the main goal of this narrative review was to assess the most important data on the efficacy of these novel antibiotics in order to provide some guidance on their application in clinical practice. As such, this review is considered appropriate for this purpose. 
For most antibiotics, studies have been published about combination therapy in in vitro models or animal studies. Although results might seem promising, in most cases, results have not been confirmed in human studies yet. Caution is needed in extrapolating these findings to the clinical setting, even more because of possible antagonism as might have been observed in the preclinical setting.

In order to use these new-generation antibiotics, antimicrobial susceptibility tests and breakpoints should be available in the microbiology laboratories. For all antibiotics reviewed here, except for omadacycline, EUCAST breakpoints for staphylococci are available (EUCAST version 10.0). For streptococci, EUCAST breakpoints are available for all agents except for telavancin and omadacycline. For enterococci, only linezolid EUCAST breakpoints are available. Clinical and Laboratory Standards Institute breakpoints may be used to overcome this problem.

In conclusion, promising antibiotics for the treatment of Gram-positive infections have been approved in the last 20 years. However, these new antibiotics should not be used as first-line therapy as clinical data are limited. Only in case of resistance to firstand second-line agents, allergy, or in clinical and/or microbiological failure should these antibiotics be considered. In these cases, the practical approach in this review, including the summary table, could be helpful to determine which of these antibiotics would be the preferable agent to use.

Author Contributions: Conceptualization: A.B., N.J.V., E.Y., H.I.B.; Writing, preparation of original draft: A.B.; Writing, reviewing and editing: N.J.V., H.I.B., E.Y., A.B. All authors have read and agreed to the published version of the manuscript.

Funding: This research received no external funding.

Institutional Review Board Statement: Not applicable.

Informed Consent Statement: Not applicable.

Conflicts of Interest: The authors declare no conflict of interest.

\section{References}

1. Habib, G.; Lancellotti, P.; Antunes, M.J.; Bongiorni, M.G.; Casalta, J.P.; Del Zotti, F.; Dulgheru, R.; El Khoury, G.; Erba, P.A.; Iung, B.; et al. 2015 ESC Guidelines for the management of infective endocarditis: The Task Force for the Management of Infective Endocarditis of the European Society of Cardiology (ESC). Endorsed by: European Association for Cardio-Thoracic Surgery (EACTS), the European Association of Nuclear Medicine (EANM). Eur. Heart J. 2015, 36, 3075-3128. [CrossRef]

2. Osmon, D.R.; Berbari, E.F.; Berendt, A.R.; Lew, D.; Zimmerli, W.; Steckelberg, J.M.; Rao, N.; Hanssen, A.; Wilson, W.R. Diagnosis and management of prosthetic joint infection: Clinical practice guidelines by the Infectious Diseases Society of America. Clin. Infect Dis. 2013, 56, e1-e25. [CrossRef] [PubMed]

3. Kaplan, J.B. Antibiotic-induced biofilm formation. Int. J. Artif. Organs 2011, 34, 737-751. [CrossRef] [PubMed]

4. Mah, T.F.; O'Toole, G.A. Mechanisms of biofilm resistance to antimicrobial agents. Trends Microbiol. 2001, 9, 34-39. [CrossRef]

5. Pani, A.; Colombo, F.; Agnelli, F.; Frantellizzi, V.; Baratta, F.; Pastori, D.; Scaglione, F. Off-label use of ceftaroline fosamil: A systematic review. Int. J. Antimicrob. Agents 2019, 54, 562-571. [CrossRef] [PubMed]

6. Thomas, G.; Henao-Martinez, A.F.; Franco-Paredes, C.; Chastain, D.B. Treatment of osteoarticular, cardiovascular, intravascularcatheter-related and other complicated infections with dalbavancin and oritavancin: A systematic review. Int. J. Antimicrob. Agents 2020, 56, 106069. [CrossRef]

7. Abbas, M.; Paul, M.; Huttner, A. New and improved? A review of novel antibiotics for Gram-positive bacteria. Clin. Microbiol. Infect. 2017, 23, 697-703. [CrossRef] [PubMed]

8. Tirupathi, R.; Areti, S.; Salim, S.A.; Palabindala, V.; Jonnalagadda, N. Acute bacterial skin and soft tissue infections: New drugs in ID armamentarium. J. Community Hosp. Intern. Med. Perspect. 2019, 9, 310-313. [CrossRef]

9. Bassetti, M.; Carnelutti, A.; Castaldo, N.; Peghin, M. Important new therapies for methicillin-resistant Staphylococcus aureus. Expert Opin. Pharm. 2019, 20, 2317-2334. [CrossRef]

10. Bassetti, M.; Magnasco, L.; Del Puente, F.; Giacobbe, D.R. Role of new antibiotics in the treatment of acute bacterial skin and skin-structure infections. Curr. Opin. Infect. Dis. 2020, 33, 110-120. [CrossRef] [PubMed]

11. Golan, Y. Current Treatment Options for Acute Skin and Skin-structure Infections. Clin. Infect. Dis. 2019, 68, S206-S212. [CrossRef] [PubMed] 
12. Ishikawa, T.; Matsunaga, N.; Tawada, H.; Kuroda, N.; Nakayama, Y.; Ishibashi, Y.; Tomimoto, M.; Ikeda, Y.; Tagawa, Y.; Iizawa, Y.; et al. TAK-599, a novel N-phosphono type prodrug of anti-MRSA cephalosporin T-91825: Synthesis, physicochemical and pharmacological properties. Bioorganic Med. Chem. 2003, 11, 2427-2437. [CrossRef]

13. Kaushik, D.; Rathi, S.; Jain, A. Ceftaroline: A comprehensive update. Int. J. Antimicrob. Agents 2011, 37, 389-395. [CrossRef] [PubMed]

14. Righi, E. Ceftaroline and Ceftaroline-Avibactam. In Kucers' the Use of Antibiotics, 7th ed.; Grayson, M.L., Ed.; CRC Press: Boca Raton, FL, USA, 2018; Volume 1, pp. 603-607.

15. EMA. Annex 1 Summary of Product Characteristics; EMA: Amsterdam, The Netherlands, 2012.

16. EUCAST. The European Committee on Antimicrobial Susceptibility Testing. Breakpoint Tables for Interpretation of MICs and Zone Diameters. Available online: http:/ / www.eucast.org (accessed on 8 February 2021).

17. Cheng, K.; Pypstra, R.; Yan, J.L.; Hammond, J. Summary of the safety and tolerability of two treatment regimens of ceftaroline fosamil: $600 \mathrm{mg}$ every $8 \mathrm{~h}$ versus $600 \mathrm{mg}$ every $12 \mathrm{~h}$. J. Antimicrob. Chemother. 2019, 74, 1086-1091. [CrossRef] [PubMed]

18. Dryden, M.; Zhang, Y.; Wilson, D.; Iaconis, J.P.; Gonzalez, J. A Phase III, randomized, controlled, non-inferiority trial of ceftaroline fosamil $600 \mathrm{mg}$ every $8 \mathrm{~h}$ versus vancomycin plus aztreonam in patients with complicated skin and soft tissue infection with systemic inflammatory response or underlying comorbidities. J. Antimicrob. Chemother. 2016, 71, 3575-3584. [CrossRef]

19. Perrottet, N.; Steinrucken, J.; Chan, M.; Pannatier, A.; Borens, O.; Yusuf, E.; Trampuz, A. Efficacy and safety of high-dose daptomycin $(>6 \mathrm{mg} / \mathrm{kg}$ ) for complicated bone and joint infections and implant-associated infections caused by Gram-positive bacteria. Int. J. Antimicrob. Agents 2015, 46, 480-482. [CrossRef] [PubMed]

20. Russo, A.; Peghin, M.; Givone, F.; Ingani, M.; Graziano, E.; Bassetti, M. Daptomycin-containing regimens for treatment of Gram-positive endocarditis. Int. J. Antimicrob. Agents 2019, 54, 423-434. [CrossRef]

21. Telles, J.P.; Cieslinski, J.; Tuon, F.F. Daptomycin to bone and joint infections and prosthesis joint infections: A systematic review. Braz. J. Infect. Dis. 2019, 23, 191-196. [CrossRef] [PubMed]

22. Destache, C.J.; Guervil, D.J.; Kaye, K.S. Ceftaroline fosamil for the treatment of Gram-positive endocarditis: CAPTURE study experience. Int. J. Antimicrob. Agents 2019, 53, 644-649. [CrossRef]

23. Johnson, L.B.; Ramani, A.; Guervil, D.J. Use of Ceftaroline Fosamil in Osteomyelitis: CAPTURE Study Experience. BMC Infect. Dis. 2019, 19, 183. [CrossRef]

24. Fabre, V.; Ferrada, M.; Buckel, W.R.; Avdic, E.; Cosgrove, S.E. Ceftaroline in Combination With Trimethoprim-Sulfamethoxazole for Salvage Therapy of Methicillin-Resistant Staphylococcus aureus Bacteremia and Endocarditis. Open Forum Infect. Dis. 2014, 1, ofu046. [CrossRef]

25. Casapao, A.M.; Davis, S.L.; Barr, V.O.; Klinker, K.P.; Goff, D.A.; Barber, K.E.; Kaye, K.S.; Mynatt, R.P.; Molloy, L.M.; Pogue, J.M.; et al. Large retrospective evaluation of the effectiveness and safety of ceftaroline fosamil therapy. Antimicrob. Agents Chemother. 2014, 58, 2541-2546. [CrossRef]

26. Paladino, J.A.; Jacobs, D.M.; Shields, R.K.; Taylor, J.; Bader, J.; Adelman, M.H.; Wilton, G.J.; Crane, J.K.; Schentag, J.J. Use of ceftaroline after glycopeptide failure to eradicate meticillin-resistant Staphylococcus aureus bacteraemia with elevated vancomycin minimum inhibitory concentrations. Int. J. Antimicrob. Agents 2014, 44, 557-563. [CrossRef] [PubMed]

27. Arshad, S.; Huang, V.; Hartman, P.; Perri, M.B.; Moreno, D.; Zervos, M.J. Ceftaroline fosamil monotherapy for methicillin-resistant Staphylococcus aureus bacteremia: A comparative clinical outcomes study. Int. J. Infect. Dis. 2017, 57, 27-31. [CrossRef] [PubMed]

28. Eliazar, J.; Johnson, T.; Chbib, C. Pre-clinical impact of the synergistic mechanism of daptomycin and ceftaroline in patients with methicillin-resistant Staphylococcus aureus bacteremia infections. Curr. Clin. Pharmacol. 2021. [CrossRef]

29. Hutton, M.A.; Sundaram, A.; Perri, M.B.; Zervos, M.J.; Herc, E.S. Assessment of invitrosynergy of daptomycin or vancomycin plus ceftaroline for daptomycin non-susceptible Staphylococcus aureus. Diagn Microbiol. Infect. Dis. 2020, 98, 115126. [CrossRef] [PubMed]

30. Sakoulas, G.; Moise, P.A.; Casapao, A.M.; Nonejuie, P.; Olson, J.; Okumura, C.Y.; Rybak, M.J.; Kullar, R.; Dhand, A.; Rose, W.E.; et al. Antimicrobial salvage therapy for persistent staphylococcal bacteremia using daptomycin plus ceftaroline. Clin. Ther. 2014, 36, 1317-1333. [CrossRef] [PubMed]

31. Shafiq, I.; Bulman, Z.P.; Spitznogle, S.L.; Osorio, J.E.; Reilly, I.S.; Lesse, A.J.; Parameswaran, G.I.; Mergenhagen, K.A.; Tsuji, B.T. A combination of ceftaroline and daptomycin has synergistic and bactericidal activity in vitro against daptomycin nonsusceptible methicillin-resistant Staphylococcus aureus (MRSA). Infect. Dis. 2017, 49, 410-416. [CrossRef] [PubMed]

32. Zasowski, E.J.; Trinh, T.D.; Claeys, K.C.; Casapao, A.M.; Sabagha, N.; Lagnf, A.M.; Klinker, K.P.; Davis, S.L.; Rybak, M.J. Multicenter Observational Study of Ceftaroline Fosamil for Methicillin-Resistant Staphylococcus aureus Bloodstream Infections. Antimicrob. Agents Chemother. 2017, 61, 61. [CrossRef] [PubMed]

33. Hornak, J.P.; Anjum, S.; Reynoso, D. Adjunctive ceftaroline in combination with daptomycin or vancomycin for complicated methicillin-resistant Staphylococcus aureus bacteremia after monotherapy failure. Adv. Infect. Dis. 2019, 6, 2049936119886504. [CrossRef] [PubMed]

34. McCreary, E.K.; Kullar, R.; Geriak, M.; Zasowski, E.J.; Rizvi, K.; Schulz, L.T.; Ouellette, K.; Vasina, L.; Haddad, F.; Rybak, M.J.; et al. Multicenter Cohort of Patients With Methicillin-Resistant Staphylococcus aureus Bacteremia Receiving Daptomycin Plus Ceftaroline Compared With Other MRSA Treatments. Open Forum Infect. Dis. 2020, 7, ofz538. [CrossRef] [PubMed] 
35. Geriak, M.; Haddad, F.; Rizvi, K.; Rose, W.; Kullar, R.; LaPlante, K.; Yu, M.; Vasina, L.; Ouellette, K.; Zervos, M.; et al. Clinical Data on Daptomycin plus Ceftaroline versus Standard of Care Monotherapy in the Treatment of Methicillin-Resistant Staphylococcus aureus Bacteremia. Antimicrob. Agents Chemother. 2019, 63, e02483-18. [CrossRef] [PubMed]

36. Muller, A.E.; Gyssens, I.C. Daptomycin. In Kucers' The Use of Antibiotics; Grayson, M.L., Ed.; CRC Press: Boca Raton, FL, USA, 2018; Volume 1, pp. 866-907.

37. Wang, S.Z.; Hu, J.T.; Zhang, C.; Zhou, W.; Chen, X.F.; Jiang, L.Y.; Tang, Z.H. The safety and efficacy of daptomycin versus other antibiotics for skin and soft-tissue infections: A meta-analysis of randomised controlled trials. BMJ Open 2014, 4, e004744. [CrossRef]

38. EMA. Daptomycin: Summary of Product Characteristics; EMA: Amsterdam, The Netherlands, 2010.

39. Balli, E.P.; Venetis, C.A.; Miyakis, S. Systematic review and meta-analysis of linezolid versus daptomycin for treatment of vancomycin-resistant enterococcal bacteremia. Antimicrob. Agents Chemother. 2014, 58, 734-739. [CrossRef] [PubMed]

40. Shi, C.; Jin, W.; Xie, Y.; Zhou, D.; Xu, S.; Li, Q.; Lin, N. Efficacy and safety of daptomycin versus linezolid treatment in patients with vancomycin-resistant enterococcal bacteraemia: An updated systematic review and meta-analysis. J. Glob. Antimicrob. Resist. 2020, 21, 235-245. [CrossRef]

41. Kullar, R.; Casapao, A.M.; Davis, S.L.; Levine, D.P.; Zhao, J.J.; Crank, C.W.; Segreti, J.; Sakoulas, G.; Cosgrove, S.E.; Rybak, M.J. A multicentre evaluation of the effectiveness and safety of high-dose daptomycin for the treatment of infective endocarditis. J. Antimicrob. Chemother. 2013, 68, 2921-2926. [CrossRef] [PubMed]

42. Britt, N.S.; Potter, E.M.; Patel, N.; Steed, M.E. Comparative Effectiveness and Safety of Standard-, Medium-, and High-Dose Daptomycin Strategies for the Treatment of Vancomycin-Resistant Enterococcal Bacteremia Among Veterans Affairs Patients. Clin. Infect. Dis. 2017, 64, 605-613. [CrossRef]

43. Chuang, Y.C.; Lin, H.Y.; Chen, P.Y.; Lin, C.Y.; Wang, J.T.; Chen, Y.C.; Chang, S.C. Effect of Daptomycin Dose on the Outcome of Vancomycin-Resistant, Daptomycin-Susceptible Enterococcus faecium Bacteremia. Clin. Infect. Dis. 2017, 64, 1026-1034. [CrossRef]

44. Timbrook, T.T.; Caffrey, A.R.; Luther, M.K.; Lopes, V.; LaPlante, K.L. Association of Higher Daptomycin Dose (7 mg/kg or Greater) with Improved Survival in Patients with Methicillin-Resistant Staphylococcus aureus Bacteremia. Pharmacotherapy 2018, 38, 189-196. [CrossRef] [PubMed]

45. Claeys, K.C.; Zasowski, E.J.; Casapao, A.M.; Lagnf, A.M.; Nagel, J.L.; Nguyen, C.T.; Hallesy, J.A.; Compton, M.T.; Kaye, K.S.; Levine, D.P.; et al. Daptomycin Improves Outcomes Regardless of Vancomycin MIC in a Propensity-Matched Analysis of Methicillin-Resistant Staphylococcus aureus Bloodstream Infections. Antimicrob. Agents Chemother. 2016, 60, 5841-5848. [CrossRef] [PubMed]

46. Malizos, K.; Sarma, J.; Seaton, R.A.; Militz, M.; Menichetti, F.; Riccio, G.; Gaudias, J.; Trostmann, U.; Pathan, R.; Hamed, K. Daptomycin for the treatment of osteomyelitis and orthopaedic device infections: Real-world clinical experience from a European registry. Eur. J. Clin. Microbiol. Infect. Dis. 2016, 35, 111-118. [CrossRef] [PubMed]

47. Miro, J.M.; Garcia-de-la-Maria, C.; Armero, Y.; Soy, D.; Moreno, A.; del Rio, A.; Almela, M.; Sarasa, M.; Mestres, C.A.; Gatell, J.M.; et al. Addition of gentamicin or rifampin does not enhance the effectiveness of daptomycin in treatment of experimental endocarditis due to methicillin-resistant Staphylococcus aureus. Antimicrob. Agents Chemother. 2009, 53, $4172-4177$. [CrossRef] [PubMed]

48. El Haj, C.; Murillo, O.; Ribera, A.; Vivas, M.; Garcia-Somoza, D.; Tubau, F.; Cabellos, C.; Cabo, J.; Ariza, J. Daptomycin combinations as alternative therapies in experimental foreign-body infection caused by meticillin-susceptible Staphylococcus aureus. Int. J. Antimicrob. Agents 2015, 46, 189-195. [CrossRef] [PubMed]

49. Parra-Ruiz, J.; Vidaillac, C.; Rose, W.E.; Rybak, M.J. Activities of high-dose daptomycin, vancomycin, and moxifloxacin alone or in combination with clarithromycin or rifampin in a novel in vitro model of Staphylococcus aureus biofilm. Antimicrob. Agents Chemother. 2010, 54, 4329-4334. [CrossRef]

50. Garrigos, C.; Murillo, O.; Euba, G.; Verdaguer, R.; Tubau, F.; Cabellos, C.; Cabo, J.; Ariza, J. Efficacy of usual and high doses of daptomycin in combination with rifampin versus alternative therapies in experimental foreign-body infection by methicillinresistant Staphylococcus aureus. Antimicrob. Agents Chemother. 2010, 54, 5251-5256. [CrossRef]

51. Stein, C.; Makarewicz, O.; Forstner, C.; Weis, S.; Hagel, S.; Loffler, B.; Pletz, M.W. Should daptomycin-rifampin combinations for MSSA/MRSA isolates be avoided because of antagonism? Infection 2016, 44, 499-504. [CrossRef]

52. Garcia-de-la-Maria, C.; Gasch, O.; Garcia-Gonzalez, J.; Soy, D.; Shaw, E.; Ambrosioni, J.; Almela, M.; Pericas, J.M.; Tellez, A.; Falces, C.; et al. The Combination of Daptomycin and Fosfomycin Has Synergistic, Potent, and Rapid Bactericidal Activity against Methicillin-Resistant Staphylococcus aureus in a Rabbit Model of Experimental Endocarditis. Antimicrob. Agents Chemother. 2018, 62. [CrossRef]

53. Pujol, M.; Miro, J.M.; Shaw, E.; Aguado, J.M.; San-Juan, R.; Puig-Asensio, M.; Pigrau, C.; Calbo, E.; Montejo, M.; RodriguezAlvarez, R.; et al. Daptomycin plus Fosfomycin versus Daptomycin Alone for Methicillin-Resistant Staphylococcus aureus Bacteremia and Endocarditis. A Randomized Clinical Trial. Clin. Infect. Dis. 2020. [CrossRef] [PubMed]

54. Ghazi, I.M.; Kuti, J.L.; Nicolau, D.P. Telavancin. In Kucers' The Use of Antibiotics; Grayson, M.L., Ed.; CRC Press: Boca Raton, FL, USA, 2018; pp. 930-939.

55. EMA. Vibativ-Telavancin; EMA: Amsterdam, The Netherlands, 2018.

56. FDA. Drug Approval Package VIBATIV (Telavancin) for Injection; FDA: White Oak, MD, USA, 2013. 
57. Rubinstein, E.; Lalani, T.; Corey, G.R.; Kanafani, Z.A.; Nannini, E.C.; Rocha, M.G.; Rahav, G.; Niederman, M.S.; Kollef, M.H.; Shorr, A.F.; et al. Telavancin versus vancomycin for hospital-acquired pneumonia due to gram-positive pathogens. Clin. Infect. Dis. 2011, 52, 31-40. [CrossRef] [PubMed]

58. Barriere, S.L. The ATTAIN trials: Efficacy and safety of telavancin compared with vancomycin for the treatment of hospitalacquired and ventilator-associated bacterial pneumonia. Future Microbiol. 2014, 9, 281-289. [CrossRef] [PubMed]

59. FDA. Risk Assessment and Risk Mitigation Reviews Research; FDA: White Oak, MD, USA, 2013.

60. FDA. Supplement Approval. Release from REMS Requirement; FDA: White Oak, MD, USA, 2017.

61. Joson, J.; Grover, C.; Downer, C.; Pujar, T.; Heidari, A. Successful treatment of methicillin-resistant Staphylococcus aureus mitral valve endocarditis with sequential linezolid and telavancin monotherapy following daptomycin failure. J. Antimicrob. Chemother. 2011, 66, 2186-2188. [CrossRef] [PubMed]

62. Marcos, L.A.; Camins, B.C. Successful treatment of vancomycin-intermediate Staphylococcus aureus pacemaker lead infective endocarditis with telavancin. Antimicrob. Agents Chemother. 2010, 54, 5376-5378. [CrossRef]

63. Nace, H.; Lorber, B. Successful treatment of methicillin-resistant Staphylococcus aureus endocarditis with telavancin. J. Antimicrob. Chemother. 2010, 65, 1315-1316. [CrossRef] [PubMed]

64. Ruggero, M.A.; Peaper, D.R.; Topal, J.E. Telavancin for refractory methicillin-resistant Staphylococcus aureus bacteremia and infective endocarditis. Infect. Dis. 2015, 47, 379-384. [CrossRef]

65. Reilly, J.; Jacobs, M.A.; Friedman, B.; Cleveland, K.O.; Lombardi, D.A.; Castaneda-Ruiz, B. Clinical Experience with Telavancin for the Treatment of Patients with Bacteremia and Endocarditis: Real-World Results from the Telavancin Observational Use Registry (TOUR). Drugs Real World Outcomes 2020, 7, 179-189. [CrossRef] [PubMed]

66. Harting, J.; Fernandez, F.; Kelley, R.; Wiemken, T.; Peyrani, P.; Ramirez, J. Telavancin for the treatment of methicillin-resistant Staphylococcus aureus bone and joint infections. Diagn. Microbiol. Infect. Dis. 2017, 89, 294-299. [CrossRef] [PubMed]

67. Schroeder, C.P.; Van Anglen, L.J.; Dretler, R.H.; Adams, J.S.; Prokesch, R.C.; Luu, Q.; Krinsky, A.H. Outpatient treatment of osteomyelitis with telavancin. Int. J. Antimicrob. Agents 2017, 50, 93-96. [CrossRef]

68. Saravolatz, L.D.; Cleveland, K.O.; Rikabi, K.; Hassoun, A.; Reilly, J.; Johnson, L.B.; Spak, C.; Valenti, S.; Szpunar, S. Real-world use of telavancin in the treatment of osteomyelitis. Diagn. Microbiol. Infect. Dis. 2019, 95, 185-190. [CrossRef] [PubMed]

69. Stryjewski, M.E.; Lentnek, A.; O’Riordan, W.; Pullman, J.; Tambyah, P.A.; Miro, J.M.; Fowler, V.G., Jr.; Barriere, S.L.; Kitt, M.M.; Corey, G.R. A randomized Phase 2 trial of telavancin versus standard therapy in patients with uncomplicated Staphylococcus aureus bacteremia: The ASSURE study. BMC Infect. Dis. 2014, 14, 289. [CrossRef] [PubMed]

70. Chaftari, A.M.; Hachem, R.; Jordan, M.; Garoge, K.; Al Hamal, Z.; El Zakhem, A.; Viola, G.M.; Granwehr, B.; Mulanovich, V.; Gagel, A.; et al. Case-Control Study of Telavancin as an Alternative Treatment for Gram-Positive Bloodstream Infections in Patients with Cancer. Antimicrob. Agents Chemother. 2016, 60, 239-244. [CrossRef] [PubMed]

71. Bressler, A.M.; Hassoun, A.A.; Saravolatz, L.D.; Ravenna, V.; Barnes, C.N.; Castaneda-Ruiz, B. Clinical Experience with Telavancin: Real-World Results from the Telavancin Observational Use Registry (TOUR). Drugs Real World Outcomes 2019, 6 , 183-191. [CrossRef]

72. Monogue, M.L.; Nicolau, D.P. Dalbavancin. In Kucers' The Use of Antibiotics; Grayson, M.L., Ed.; CRC Press: Boca Raton, FL, USA, 2018; Volume 1, pp. 917-929.

73. EMA. Dalbavancin: Summary of Product Characteristics; last update 18/08/2020; EMA: Amsterdam, The Netherlands, 2015.

74. FDA. Dalbavancin: Medical Review; FDA: White Oak, MD, USA, 2014.

75. Wunsch, S.; Krause, R.; Valentin, T.; Prattes, J.; Janata, O.; Lenger, A.; Bellmann-Weiler, R.; Weiss, G.; Zollner-Schwetz, I. Multicenter clinical experience of real life Dalbavancin use in gram-positive infections. Int. J. Infect. Dis. 2019, 81, 210-214. [CrossRef]

76. Hidalgo-Tenorio, C.; Vinuesa, D.; Plata, A.; Martin Davila, P.; Iftimie, S.; Sequera, S.; Loeches, B.; Lopez-Cortes, L.E.; Farinas, M.C.; Fernandez-Roldan, C.; et al. DALBACEN cohort: Dalbavancin as consolidation therapy in patients with endocarditis and/or bloodstream infection produced by gram-positive cocci. Ann. Clin. Microbiol. Antimicrob. 2019, 18, 30. [CrossRef]

77. Tobudic, S.; Forstner, C.; Burgmann, H.; Lagler, H.; Ramharter, M.; Steininger, C.; Vossen, M.G.; Winkler, S.; Thalhammer, F. Dalbavancin as Primary and Sequential Treatment for Gram-Positive Infective Endocarditis: 2-Year Experience at the General Hospital of Vienna. Clin. Infect. Dis. 2018, 67, 795-798. [CrossRef]

78. Rappo, U.; Puttagunta, S.; Shevchenko, V.; Shevchenko, A.; Jandourek, A.; Gonzalez, P.L.; Suen, A.; Mas Casullo, V.; Melnick, D.; Miceli, R.; et al. Dalbavancin for the Treatment of Osteomyelitis in Adult Patients: A Randomized Clinical Trial of Efficacy and Safety. Open Forum Infect. Dis. 2019, 6, ofy331. [CrossRef] [PubMed]

79. Morata, L.; Cobo, J.; Fernandez-Sampedro, M.; Guisado Vasco, P.; Ruano, E.; Lora-Tamayo, J.; Sanchez Somolinos, M.; Gonzalez Ruano, P.; Rico Nieto, A.; Arnaiz, A.; et al. Safety and Efficacy of Prolonged Use of Dalbavancin in Bone and Joint Infections. Antimicrob. Agents Chemother. 2019, 63. [CrossRef]

80. Raad, I.; Darouiche, R.; Vazquez, J.; Lentnek, A.; Hachem, R.; Hanna, H.; Goldstein, B.; Henkel, T.; Seltzer, E. Efficacy and safety of weekly dalbavancin therapy for catheter-related bloodstream infection caused by gram-positive pathogens. Clin. Infect. Dis. 2005, 40, 374-380. [CrossRef] [PubMed]

81. Ajaka, L.; Heil, E.; Schmalzle, S. Dalbavancin in the Treatment of Bacteremia and Endocarditis in People with Barriers to Standard Care. Antibiotics 2020, 9, 700. [CrossRef] [PubMed] 
82. Hitzenbichler, F.; Mohr, A.; Camboni, D.; Simon, M.; Salzberger, B.; Hanses, F. Dalbavancin as long-term suppressive therapy for patients with Gram-positive bacteremia due to an intravascular source-a series of four cases. Infection 2021, 49, 181-186. [CrossRef] [PubMed]

83. Baldoni, D.; Furustrand Tafin, U.; Aeppli, S.; Angevaare, E.; Oliva, A.; Haschke, M.; Zimmerli, W.; Trampuz, A. Activity of dalbavancin, alone and in combination with rifampicin, against meticillin-resistant Staphylococcus aureus in a foreign-body infection model. Int. J. Antimicrob. Agents 2013, 42, 220-225. [CrossRef]

84. So, W.; Nicolau, D.P. Oritavancin. In Kucers' The Use of Antibiotics; Grayson, M.L., Ed.; CRC Press: Boca Raton, FL, USA, 2018; Volume 1, pp. 908-916.

85. Arhin, F.F.; Draghi, D.C.; Pillar, C.M.; Parr, T.R., Jr.; Moeck, G.; Sahm, D.F. Comparative in vitro activity profile of oritavancin against recent gram-positive clinical isolates. Antimicrob. Agents Chemother. 2009, 53, 4762-4771. [CrossRef] [PubMed]

86. Bhavnani, S.M.; Owen, J.S.; Loutit, J.S.; Porter, S.B.; Ambrose, P.G. Pharmacokinetics, safety, and tolerability of ascending single intravenous doses of oritavancin administered to healthy human subjects. Diagn. Microbiol. Infect. Dis. 2004, 50, 95-102. [CrossRef]

87. Billeter, M.; Zervos, M.J.; Chen, A.Y.; Dalovisio, J.R.; Kurukularatne, C. Dalbavancin: A novel once-weekly lipoglycopeptide antibiotic. Clin. Infect. Dis. 2008, 46, 577-583. [CrossRef] [PubMed]

88. EMA. Oritavancin Summary of Product Characteristics; EMA: Amsterdam, The Netherlands, 2020.

89. Brade, K.D.; Rybak, J.M.; Rybak, M.J. Oritavancin: A New Lipoglycopeptide Antibiotic in the Treatment of Gram-Positive Infections. Infect. Dis. 2016, 5, 1-15. [CrossRef]

90. Johnson, J.A.; Feeney, E.R.; Kubiak, D.W.; Corey, G.R. Prolonged Use of Oritavancin for Vancomycin-Resistant Enterococcus faecium Prosthetic Valve Endocarditis. Open Forum Infect. Dis. 2015, 2, ofv156. [CrossRef] [PubMed]

91. Van Hise, N.W.; Chundi, V.; Didwania, V.; Anderson, M.; McKinsey, D.; Roig, I.; Sharma, A.; Petrak, R.M. Treatment of Acute Osteomyelitis with Once-Weekly Oritavancin: A Two-Year, Multicenter, Retrospective Study. Drugs Real World Outcomes 2020, 7 , 41-45. [CrossRef]

92. Redell, M.; Sierra-Hoffman, M.; Assi, M.; Bochan, M.; Chansolme, D.; Gandhi, A.; Sheridan, K.; Soosaipillai, I.; Walsh, T.; Massey, J. The CHROME Study, a Real-world Experience of Single- and Multiple-Dose Oritavancin for Treatment of Gram-Positive Infections. Open Forum Infect. Dis. 2019, 6, ofz479. [CrossRef] [PubMed]

93. Sparham, S.J.; Howden, B.P. Linezolid. In Kucers' The Use of Antibiotics; Grayson, M.L., Ed.; CRC Press: Boca Raton, FL, USA, 2018; Volume 1, pp. 1293-1347.

94. Stalker, D.J.; Jungbluth, G.L.; Hopkins, N.K.; Batts, D.H. Pharmacokinetics and tolerance of single- and multiple-dose oral or intravenous linezolid, an oxazolidinone antibiotic, in healthy volunteers. J. Antimicrob. Chemother. 2003, 51, 1239-1246. [CrossRef]

95. Welshman, I.R.; Sisson, T.A.; Jungbluth, G.L.; Stalker, D.J.; Hopkins, N.K. Linezolid absolute bioavailability and the effect of food on oral bioavailability. Biopharm Drug Dispos 2001, 22, 91-97. [CrossRef]

96. Capsule, H. Linezolid: Summary of Product Characteristics; Pfizer AB: Sollentuna, Sweden, 2009.

97. Bishop, E.; Melvani, S.; Howden, B.P.; Charles, P.G.; Grayson, M.L. Good clinical outcomes but high rates of adverse reactions during linezolid therapy for serious infections: A proposed protocol for monitoring therapy in complex patients. Antimicrob. Agents Chemother. 2006, 50, 1599-1602. [CrossRef]

98. Falagas, M.E.; Siempos, I.I.; Vardakas, K.Z. Linezolid versus glycopeptide or beta-lactam for treatment of Gram-positive bacterial infections: Meta-analysis of randomised controlled trials. Lancet Infect. Dis. 2008, 8, 53-66. [CrossRef]

99. Crass, R.L.; Cojutti, P.G.; Pai, M.P.; Pea, F. Reappraisal of Linezolid Dosing in Renal Impairment To Improve Safety. Antimicrob. Agents Chemother. 2019, 63. [CrossRef]

100. Falagas, M.E.; Manta, K.G.; Ntziora, F.; Vardakas, K.Z. Linezolid for the treatment of patients with endocarditis: A systematic review of the published evidence. J. Antimicrob. Chemother. 2006, 58, 273-280. [CrossRef] [PubMed]

101. Colli, A.; Campodonico, R.; Gherli, T. Early switch from vancomycin to oral linezolid for treatment of gram-positive heart valve endocarditis. Ann. Thorac. Surg. 2007, 84, 87-91. [CrossRef] [PubMed]

102. Munoz, P.; Rodriguez-Creixems, M.; Moreno, M.; Marin, M.; Ramallo, V.; Bouza, E.; Game Study, G. Linezolid therapy for infective endocarditis. Clin. Microbiol. Infect. 2007, 13, 211-215. [CrossRef] [PubMed]

103. Rayner, C.R.; Baddour, L.M.; Birmingham, M.C.; Norden, C.; Meagher, A.K.; Schentag, J.J. Linezolid in the treatment of osteomyelitis: Results of compassionate use experience. Infection 2004, 32, 8-14. [CrossRef] [PubMed]

104. Vercillo, M.; Patzakis, M.J.; Holtom, P.; Zalavras, C.G. Linezolid in the treatment of implant-related chronic osteomyelitis. Clin. Orthop Relat Res. 2007, 461, 40-43. [CrossRef] [PubMed]

105. Rao, N.; Ziran, B.H.; Hall, R.A.; Santa, E.R. Successful treatment of chronic bone and joint infections with oral linezolid. Clin. Orthop. Relat. Res. 2004, 427, 67-71. [CrossRef] [PubMed]

106. Jang, H.C.; Kim, S.H.; Kim, K.H.; Kim, C.J.; Lee, S.; Song, K.H.; Jeon, J.H.; Park, W.B.; Kim, H.B.; Park, S.W.; et al. Salvage treatment for persistent methicillin-resistant Staphylococcus aureus bacteremia: Efficacy of linezolid with or without carbapenem. Clin. Infect. Dis. 2009, 49, 395-401. [CrossRef]

107. Park, H.J.; Kim, S.H.; Kim, M.J.; Lee, Y.M.; Park, S.Y.; Moon, S.M.; Park, K.H.; Chong, Y.P.; Lee, S.O.; Choi, S.H.; et al. Efficacy of linezolid-based salvage therapy compared with glycopeptide-based therapy in patients with persistent methicillin-resistant Staphylococcus aureus bacteremia. J. Infect. 2012, 65, 505-512. [CrossRef] 
108. El Haj, C.; Murillo, O.; Ribera, A.; Lloberas, N.; Gomez-Junyent, J.; Tubau, F.; Fontova, P.; Cabellos, C.; Ariza, J. Evaluation of linezolid or trimethoprim/sulfamethoxazole in combination with rifampicin as alternative oral treatments based on an in vitro pharmacodynamic model of staphylococcal biofilm. Int. J. Antimicrob. Agents 2018, 51, 854-861. [CrossRef] [PubMed]

109. Nguyen, S.; Pasquet, A.; Legout, L.; Beltrand, E.; Dubreuil, L.; Migaud, H.; Yazdanpanah, Y.; Senneville, E. Efficacy and tolerance of rifampicin-linezolid compared with rifampicin-cotrimoxazole combinations in prolonged oral therapy for bone and joint infections. Clin. Microbiol. Infect. 2009, 15, 1163-1169. [CrossRef] [PubMed]

110. Bidell, M.R.; Drusano, G.L.; Lodise, T.P. Tedizolid. In Kucers' The Use of Antibiotics; Grayson, M.L., Ed.; CRC Press: Boca Raton, FL, USA, 2018; Volume 1, pp. 1356-1373.

111. Carvalhaes, C.G.; Sader, H.S.; Flamm, R.K.; Mendes, R.E. Tedizolid in vitro activity against Gram-positive clinical isolates causing bone and joint infections in hospitals in the USA and Europe (2014-17). J. Antimicrob. Chemother. 2019, 74, 1928-1933. [CrossRef]

112. Flanagan, S.D.; Bien, P.A.; Munoz, K.A.; Minassian, S.L.; Prokocimer, P.G. Pharmacokinetics of tedizolid following oral administration: Single and multiple dose, effect of food, and comparison of two solid forms of the prodrug. Pharmacotherapy 2014, 34, 240-250. [CrossRef] [PubMed]

113. Flanagan, S.; Minassian, S.L.; Morris, D.; Ponnuraj, R.; Marbury, T.C.; Alcorn, H.W.; Fang, E.; Prokocimer, P. Pharmacokinetics of tedizolid in subjects with renal or hepatic impairment. Antimicrob. Agents Chemother. 2014, 58, 6471-6476. [CrossRef] [PubMed]

114. Moran, G.J.; Fang, E.; Corey, G.R.; Das, A.F.; De Anda, C.; Prokocimer, P. Tedizolid for 6 days versus linezolid for 10 days for acute bacterial skin and skin-structure infections (ESTABLISH-2): A randomised, double-blind, phase 3, non-inferiority trial. Lancet Infect. Dis. 2014, 14, 696-705. [CrossRef]

115. Prokocimer, P.; De Anda, C.; Fang, E.; Mehra, P.; Das, A. Tedizolid phosphate vs linezolid for treatment of acute bacterial skin and skin structure infections: The ESTABLISH-1 randomized trial. JAMA 2013, 309, 559-569. [CrossRef] [PubMed]

116. Lodise, T.P.; Fang, E.; Minassian, S.L.; Prokocimer, P.G. Platelet profile in patients with acute bacterial skin and skin structure infections receiving tedizolid or linezolid: Findings from the Phase 3 ESTABLISH clinical trials. Antimicrob. Agents Chemother. 2014, 58, 7198-7204. [CrossRef] [PubMed]

117. Abad, L.; Tafani, V.; Tasse, J.; Josse, J.; Chidiac, C.; Lustig, S.; Ferry, T.; Diot, A.; Laurent, F.; Valour, F. Evaluation of the ability of linezolid and tedizolid to eradicate intraosteoblastic and biofilm-embedded Staphylococcus aureus in the bone and joint infection setting. J. Antimicrob. Chemother. 2019, 74, 625-632. [CrossRef] [PubMed]

118. Chan, L.C.; Basuino, L.; Dip, E.C.; Chambers, H.F. Comparative efficacies of tedizolid phosphate, vancomycin, and daptomycin in a rabbit model of methicillin-resistant Staphylococcus aureus endocarditis. Antimicrob. Agents Chemother. 2015, 59, 3252-3256. [CrossRef]

119. Singh, K.V.; Arias, C.A.; Murray, B.E. Tedizolid as Step-Down Therapy following Daptomycin versus Continuation of Daptomycin against Enterococci and Methicillin- and Vancomycin-Resistant Staphylococcus aureus in a Rat Endocarditis Model. Antimicrob. Agents Chemother. 2020, 64. [CrossRef] [PubMed]

120. Park, K.H.; Greenwood-Quaintance, K.E.; Mandrekar, J.; Patel, R. Activity of Tedizolid in Methicillin-Resistant Staphylococcus aureus Experimental Foreign Body-Associated Osteomyelitis. Antimicrob. Agents Chemother. 2016, 60, 6568-6572. [CrossRef]

121. Park, K.H.; Greenwood-Quaintance, K.E.; Schuetz, A.N.; Mandrekar, J.N.; Patel, R. Activity of Tedizolid in Methicillin-Resistant Staphylococcus epidermidis Experimental Foreign Body-Associated Osteomyelitis. Antimicrob. Agents Chemother. $2017,61$. [CrossRef] [PubMed]

122. Smith, J.R.; Yim, J.; Rice, S.; Stamper, K.; Kebriaei, R.; Rybak, M.J. Combination of Tedizolid and Daptomycin against MethicillinResistant Staphylococcus aureus in an In Vitro Model of Simulated Endocardial Vegetations. Antimicrob. Agents Chemother. 2018, 62. [CrossRef] [PubMed]

123. Mangalore, R.P.; Kwong, J.; Grayson, M.L. Delafloxacin. In Kucers' The Use of Antibiotics; Grayson, M.L., Ed.; CRC Press: Boca Raton, FL, USA, 2018; Volume 2, pp. 2132-2138.

124. McCurdy, S.; Lawrence, L.; Quintas, M.; Woosley, L.; Flamm, R.; Tseng, C.; Cammarata, S. In Vitro Activity of Delafloxacin and Microbiological Response against Fluoroquinolone-Susceptible and Nonsusceptible Staphylococcus aureus Isolates from Two Phase 3 Studies of Acute Bacterial Skin and Skin Structure Infections. Antimicrob. Agents Chemother. 2017, 61. [CrossRef]

125. Pfaller, M.A.; Sader, H.S.; Rhomberg, P.R.; Flamm, R.K. In Vitro Activity of Delafloxacin against Contemporary Bacterial Pathogens from the United States and Europe, 2014. Antimicrob. Agents Chemother. 2017, 61. [CrossRef] [PubMed]

126. Shortridge, D.; Flamm, R.K. Comparative In Vitro Activities of New Antibiotics for the Treatment of Skin Infections. Clin. Infect. Dis. 2019, 68, S200-S205. [CrossRef]

127. Van Bambeke, F. Delafloxacin, a non-zwitterionic fluoroquinolone in Phase III of clinical development: Evaluation of its pharmacology, pharmacokinetics, pharmacodynamics and clinical efficacy. Future Microbiol. 2015, 10, 1111-1123. [CrossRef] [PubMed]

128. Lemaire, S.; Tulkens, P.M.; Van Bambeke, F. Contrasting effects of acidic $\mathrm{pH}$ on the extracellular and intracellular activities of the anti-gram-positive fluoroquinolones moxifloxacin and delafloxacin against Staphylococcus aureus. Antimicrob. Agents Chemother. 2011, 55, 649-658. [CrossRef] [PubMed]

129. Hoover, R.; Hunt, T.; Benedict, M.; Paulson, S.K.; Lawrence, L.; Cammarata, S.; Sun, E. Safety, Tolerability, and Pharmacokinetic Properties of Intravenous Delafloxacin After Single and Multiple Doses in Healthy Volunteers. Clin. Ther. 2016, 38 , 53-65. [CrossRef] [PubMed] 
130. Shiu, J.; Ting, G.; Kiang, T.K. Clinical Pharmacokinetics and Pharmacodynamics of Delafloxacin. Eur. J. Drug Metab. Pharm. 2019, 44, 305-317. [CrossRef] [PubMed]

131. Hoover, R.; Hunt, T.; Benedict, M.; Paulson, S.K.; Lawrence, L.; Cammarata, S.; Sun, E. Single and Multiple Ascending-dose Studies of Oral Delafloxacin: Effects of Food, Sex, and Age. Clin. Ther. 2016, 38, 39-52. [CrossRef]

132. Hoover, R.K.; Alcorn, H., Jr.; Lawrence, L.; Paulson, S.K.; Quintas, M.; Cammarata, S.K. Delafloxacin Pharmacokinetics in Subjects With Varying Degrees of Renal Function. J. Clin. Pharmacol. 2018, 58, 514-521. [CrossRef] [PubMed]

133. FDA. Box Warning; FDA: White Oak, MD, USA, 2018.

134. Lodise, T.; Corey, R.; Hooper, D.; Cammarata, S. Safety of Delafloxacin: Focus on Adverse Events of Special Interest. Open Forum Infect. Dis. 2018, 5, ofy220. [CrossRef]

135. Bauer, J.; Siala, W.; Tulkens, P.M.; Van Bambeke, F. A combined pharmacodynamic quantitative and qualitative model reveals the potent activity of daptomycin and delafloxacin against Staphylococcus aureus biofilms. Antimicrob. Agents Chemother. 2013, 57, 2726-2737. [CrossRef]

136. Siala, W.; Mingeot-Leclercq, M.P.; Tulkens, P.M.; Hallin, M.; Denis, O.; Van Bambeke, F. Comparison of the antibiotic activities of Daptomycin, Vancomycin, and the investigational Fluoroquinolone Delafloxacin against biofilms from Staphylococcus aureus clinical isolates. Antimicrob. Agents Chemother. 2014, 58, 6385-6397. [CrossRef] [PubMed]

137. Karlowsky, J.A.; Steenbergen, J.; Zhanel, G.G. Microbiology and Preclinical Review of Omadacycline. Clin. Infect. Dis. 2019, 69, S6-S15. [CrossRef]

138. Mouton, J.W.; Nabuurs-Fransen, M.H. Omadacycline. In Kucers' The Use of Antibiotics; Grayson, M.L., Ed.; CRC Press: Boca Raton, FL, USA, 2018; Volume 1, pp. 1267-1272.

139. Rodvold, K.A.; Pai, M.P. Pharmacokinetics and Pharmacodynamics of Oral and Intravenous Omadacycline. Clin. Infect. Dis. 2019, 69, S16-S22. [CrossRef]

140. Stets, R.; Popescu, M.; Gonong, J.R.; Mitha, I.; Nseir, W.; Madej, A.; Kirsch, C.; Das, A.F.; Garrity-Ryan, L.; Steenbergen, J.N.; et al. Omadacycline for Community-Acquired Bacterial Pneumonia. N. Engl. J. Med. 2019, 380, 517-527. [CrossRef]

141. EMA. Withdrawal Assessment Report. Nuzyra (Omadacycline Tosylate); EMA: Amsterdam, The Netherlands, 2019.

142. Berg, J.K.; Tzanis, E.; Garrity-Ryan, L.; Bai, S.; Chitra, S.; Manley, A.; Villano, S. Pharmacokinetics and Safety of Omadacycline in Subjects with Impaired Renal Function. Antimicrob. Agents Chemother. 2018, 62. [CrossRef] [PubMed]

143. Opal, S.; File, T.M.; van der Poll, T.; Tzanis, E.; Chitra, S.; McGovern, P.C. An Integrated Safety Summary of Omadacycline, a Novel Aminomethylcycline Antibiotic. Clin. Infect. Dis. 2019, 69, S40-S47. [CrossRef] [PubMed] 